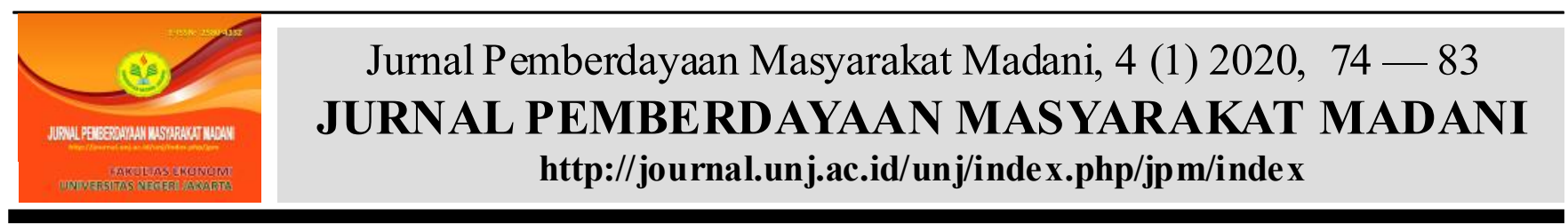

\title{
Accountability in Managing Business Funds through Budgeting to Smes
}

\author{
I Gusti Ketut Agung Ulupui ${ }^{1}$ Siti Fatimah Zahra ${ }^{1}$ Dwi Handarini ${ }^{1}$ \\ ${ }^{1}$ State University of Jakarta, Indonesia
}

\section{ARTICLE INFO}

Article history:

Received: January 2020

Accepted: May 2020

Published: July 2020

\section{ABSTRACT}

The classic problem that is still inherent in SME's activities is the lack of capital. This is also felt by SMEs in the Tarumajaya sub-district, North Bekasi, West Java. So, there is a need for appropriate fund management and budgeting. Therefore, this activity aims to provide workshops related to accountability, good procedures for managing business funds, as well as providing budgeting practices for SMEs. The method of implementing PKM activities consists of 3 stages, namely: planning, implementation, and evaluation. The workshop was held in the Hall of TPI PALIJAYA Segara Jaya Village and was attended by 54 business people with different business objects. The material was delivered in the form of theory and practice, followed by a discussion and question and answer session with the participants. Based on the results of the questionnaire survey, it was found that before this training, only $23 \%$ of the trainees stated that they had planned a business activity budget. Only $17 \%$ stated that they used to record transactions related to their business activities routinely. After this training, the participants increasingly understood the importance of budgeting in business. Thus, an assessment of $90 \%$ of participants stated that the business budget was an important matter. As for the participant's assessment of the whole set of activities, $83 \%$ stated that the material presented by the service team was important, and $77 \%$ stated it was useful. As many as $73 \%$ of participants stated that the material had been delivered by the service team clearly, and $87 \%$ of participants expressed satisfaction with the community service activities carried out by the community service team from FE UNJ.

How to cite: I Gusti Ketut Agung Ulupui, Siti Fatimah Zahra, \& Dwi Handarini. (2020). Accountability in Managing Business Funds through Budgeting to SME's. Jurnal Pemberdayaan Masyarakat Madani (JPMM), 4(1), 74-83. https://doi.org/10.21009/JPMM.004.1.06

* Corresponding Author. igka-ulupui@unj.ac.id. (I Gusti Ketut Agung Ulupui) 


\section{INTRODUCTION}

\section{Situation Analysis}

Based on the Decree of the Minister of Villages No. 126 of 2017 concerning the Determination of Priority Villages, the Target of Village Development, Development of Disadvantaged Regions, and Transmigration states that one of the disadvantaged villages is Segara Jaya Village.

Segara Jaya Village is a village in the Tarumajaya sub-district, North Bekasi, West Java, which was formed in 1945. This village has an area of approximately 1,000 ha, with a land area of 700 ha. The total population of 20,731 people is headed by a village head, 8 hamlet heads, 3 section heads, 34 neighborhood associations (RW), 88 neighborhood associations (RT). The composition of the majority population of men aged 30-40 years with the highest in education is junior high school.

The jobs that are owned by the people of Segara Jaya Village are very diverse, such as farmers, fishermen, and laborers in various home industries such as handicrafts, batik, and others. The agricultural products produced are only rice. Besides, residents who have green shellfis $\mathrm{h}$ stripping activities.

The business undertaken by the majority of the people of Segara Jaya Village belongs to the SMEs category. Segara Jaya village has a superior product, Search Batik. The marketing is done through social media. Besides, the village of Segara Jaya also makes handicrafts from shells. This craft activity is under the guidance of Youth Organization. There is also a home industry that produces doormat from patchwork.

The development of small and micro enterprises is a major driver of the real sector in Indonesia (Ministry of Trade, 2013). That is because SMEs units can absorb employment opportunities in Indonesia. However, SMEs in Indonesia still have problems in the ir survival to this day. According to the Ministry of Trade (2013), a classic problem that is still inherent in SME's business activities is the lack of capital. This is also felt by business people in the Segara Jaya Village. Also, because of the low level of education, businesses have a poor understanding of business fund management and budget preparation.

\section{Formulation of the problem}

Based on the situation analys is above, the formulation of the problem in this activity is:

1. There are still obstacles in terms of capital for SMEs in the Village of Segara Jaya, Tarumajaya District, North Bekasi.

2. Lack knowledge of SMEs entrepreneurs related to budget preparation so that it still feels difficult in managing their businesses.

\section{Purpose of Activity}

The purpose of this community service activity is to provide training (workshops) related to accountability, procedures for managing good business funds, as well as providing budgeting practice practices for SMEs. 


\section{Benefits of Activities}

The benefits of this training activity are the increased ability and know ledge of partners in terms of accountability, procedures for managing business funds and being able to draw up a business budget properly.

\section{LITERATURE REVIEW}

\section{Accountability}

Accountability comes from the Latin compare (accountability), the basic form of the word computer (taking into account) which also comes from the word pure (carrying out calculations). Accountability is one of the pillars of realizing good financial governance (Sujarweni, 2015). The accountability is also one of the principles in financial management, as written in the Minister of Home Affairs Regulation No. 113 of 2014 is accountable.

According to Nasirah (2016) states that accountability is an instrument for control activities, especially on achieving results in public services. In this connection, a performance evaluation is needed to determine the extent of achieving the results and the methods used for all of these things.

Furthermore, according to Hiskia and Ambar (2011) in Putriyanti (2012) Accountability includes the obligation to present and report various activities, especially in the area of financial administration to higher parties. The tools used for accountability are not limited to accountability reports, but also include aspects of convenience for mandators to obtain the required information, both directly and indirectly and verbally and in writing, so that accountability can grow in an environment that prioritizes openness as a basis for accountability.

\section{Business Fund Management}

According to Devi (2018), Financial management is a very important activity to manage finances which includes recording, planning, implementation, accountability and reporting starting from obtaining funds up to the use of funds, to achieve financial goals in the future. Matters in managing finances within a company are also a major key in terms of the company's operational activities and will never be separated from activities related to cash lines.

The stages of financial management are as follows:

1. Record assets/assets that have been owned

2. Record all expenses

3. Identify monthly and annual routine expenses

4. Arranging expenditure plans (budgeting).

The main functions of financial management include cash flow planning, income budgeting, financial system control, financial audits to avoid irregularities, and financial analys is reporting (Devi, 2018).

According to Putra (2018), 3 aspects must be considered in managing funds (financial), namely: 
1. Aspects of funding sources

Judging from its origin, the source of business funds can be divided into two groups, namely:

a. Funds from the company (internal).

b. Funds originating from outside the company (external), which includes funds from the owner or participation, debt/ loan, funds from government assistance, venture funds, and others.

2. Aspects of the Plan and Use of Funds.

3. Financial Supervision and Control Aspects.

\section{The Budget}

The preparation of a business budget will increase the chances of business success if it is supported by policies that are directed and assisted by careful planning. The Budget is useful in terms of planning, coordination, and supervision (Murdayanti, 2017).

Budgeting plays an important role in planning, c ontrolling, and making decisions. In the budget, the unit of activity and unit of money occupies an important position, meaning that all activities will be quantified in units of money so that the achievement of efficiency and effectiveness of the activities carried out can be measured (Poerwanto, 2017).

In preparing the budget, the following factors need to be considered: (Murdayanti, 2017)
a. Knowledge of the company's general ob- jectives and policies
b. Past data
c. Possible development of economic con- ditions

d. Knowledge of tactics, competitive strategies, and competitors' movements

e. Possible changes to government policy

f. Research for company development.

\section{MATERIAL AND METHOD}

\section{Problem Solving Framework}

Solving problems faced by SMEs in terms of capital and lack of knowledge related to budget preparation, the service team did the following:

1. Provision of material by speakers related to business fund management and good budget preparation procedures. The material provided is theoretical and practical applications through case examples.

2. Discussion and given the opportunity for question and answer session forum.

3. Explanation of various obstacles faced by SMEs.

4. Business actors get solutions related to the problems and obstacles they face.

\section{Re alization of Problem Solving}

In carrying out this PKM workshop activity, the service team provided material related to business fund management and budget preparation. The resource person delivered the material starting from the understanding of the budget, examples of preparing the budget, showing a video about the business budget, and continued with a discussion and question and answer session with participants. The last part was closed with a question and 
answer session by enthusiastic participants, seen by the many questions and answer interest and the lively atmosphere at the time of the training.

The material is delivered in the form of practical direction that can support the ir ability to apply the understanding obtained related to the preparation of business budgets and have expertise in managing their business funds. Thus, the financ ial management of his business is getting better.

The implementation of the community service activities took place in the Hall of TPI Palijaya UPTD, Segara Jaya Village, Taruma Jaya District, Bekasi. This activity was held on Wednesday, September 4, 2019, and was attended by 54 participants who were SME actors in Segara Jaya Village.

\section{Target Audience}

Targets The target of these community service activities are SMEs in the Segara Jaya Village, Taruma Jaya District, Bekasi. In its implementation, the training was attended by 54 participants who were SMEs who had various business objects such as shrimp, fish, and others.

\section{Method}

The method of implementing PKM activities consists of 3 stages, namely:

1. Planning stage: at this stage, the proposing team mapped out the problem with the SME partners.

2. Implementation phase: this second stage is the stage of efforts to realize solutions to partner problems that have been identified in the previous stage.

3. Evaluation stage: this stage is an evaluation of the implementation of community service activities that have been carried out as well as preparing reports on the results of the entire set of activities.

\section{RESULT AND DISCUSSION}

In the implementation of the PKM workshop activities, the service team provided material related to budget preparation and business fund management. In the initial session, the resource person delivered the material starting from the understanding of the budget, examples of preparing the budget, showing a video about the business budget, and continued with a discussion and question and answer session with the participants. The last part was closed with a question and answer session by enthusiastic participants, seen by the many questions and answer interest and the lively atmosphere at the time of the training.

The material is delivered in the form of practical direction that can support the ir ability to apply the understanding obtained related to the preparation of business budgets and have expertise in managing the ir business funds. Thus, the financial management of his business is getting better.

The characteristics of the trainees vary from one another. Of the 54 participants, 30 participants collected the questionnaire. Based 
on the questionnaire, the profiles of the participants were as follows:

\section{Age}

The average age of participants who took part in the workshop was 20-50 years. Data age of respondents is described in Table 6. 1.

\section{Gender}

All respondents who filled out and collected questionna ires were women because the majority of participants who attended the workshop were women. Gender of respondents is described in Table 6. 2.

\section{Business Field}

The majority of the business sectors of the workshop participants are selling fish and

Table 6. 1. Data Age of Respondents

\begin{tabular}{|c|c|}
\hline \multicolumn{1}{|c|}{ Age } & Amount (people) \\
\hline$<20$ years & 1 \\
\hline $20-50$ years & 24 \\
\hline$>50$ years & 5 \\
\hline Total & $\mathbf{3 0}$ \\
\hline
\end{tabular}

shrimp. This is because the position of the community of Segara Jaya Village is very close to the sea and there are also tourist attractions. Thus, the surrounding community chose to sell fish and shrimp as their main livelihood. Business respondents is described in Table 6. 3.

\section{Latest Education}

As for education, the majority of Segara Jaya villagers only reach the elementary school level. More people decide to go straight to work compared to continuing their education to a higher level. Education level of respondents is described in Table 6. 4.

The majority of workshop participants still combine personal needs funds with funds used for their business. So that the calculation

Table 6. 2.

Gender of Respondents

\begin{tabular}{|c|c|}
\hline Gender & Amount (Person) \\
\hline Girl & 30 \\
\hline Male & 0 \\
\hline Total & 30 \\
\hline
\end{tabular}


of funds managed in his business is still unclear and can not be known with certainty the benefits derived from his business. They still make efforts solely to meet their daily needs, without planning for future business development to be better. This is partly due to the lack of knowledge of the participants in financial management and budgeting in conducting their business activities.

Several tendencies view training materia 1 as mere rhetoric, so the service team undertakes a strategy in organizing training events, especially in the delivery of material. One way that can be done is to approach the participants as people who are directly related to the problem.

The method of delivering the material in this training is done through exposure covering basic theories about business budgets, simple question exercises related to business budgets,

Table 6.3. Business Respondents

\begin{tabular}{|l|c|}
\hline Line of B us iness & Number (person) \\
\hline Selling fis $h$ & 15 \\
\hline Selling Shrimp & 10 \\
\hline Selling Staples & 4 \\
\hline Sorter & 1 \\
\hline \multicolumn{1}{|c|}{ Total } & $\mathbf{3 0}$ \\
\hline
\end{tabular}

and videos about making business budgets. As can see in Image 1.

The presentation of the material was also carried out complete with case examples and showing examples of budget preparation tables so that the participants were able to understand the explanation of the material presented by the resource persons. The service team stressed the importance of making a good budgeting and fund management in running a business so that the creation of a business that is growing well in the future. Through good budgeting, business actors will be able to make appropriate business plans and policies.

Before this training, only $23 \%$ of participants said they had planned a business activity budget. While those who said they were accustomed to recording transactions related to their business activities routinely were only

Table 6. 4.

Education Level of Res pondents

\begin{tabular}{|l|c|}
\hline \multicolumn{1}{|c|}{ Latest Education } & Number \\
\hline Elementary School & 13 \\
\hline Junior High School & 5 \\
\hline High school & 4 \\
\hline University & 1 \\
\hline Not attending school & 7 \\
\hline \multicolumn{1}{|c|}{ Total } & $\mathbf{3 0}$ \\
\hline
\end{tabular}


$17 \%$ of the participants. After this training, participants increasingly understood the importance of budgeting in business and $90 \%$ of participants stated that preparing a business budget was an important thing to do.

Assessment of the participants in the whole set of activities, based on the results of the questionnaire it was found that $83 \%$ stated that the material presented by the service team was important, and $77 \%$ stated it was useful. As many as $73 \%$ of participants stated that the material had been delivered by the service team clearly, and $87 \%$ of participants expressed satisfaction with the service activities carried out. As can see in Diagram 1.

\section{CONCLUSION AND \\ RECOMMENDATION}

\section{Conclusion}

The community service activities that have been carried out have proven to be able to provide enlightenment in budgeting and managing business funds for SME partner partners. This can be seen from the enthusiasm of the participants in following the training activities to the end with a positive response and a dynamic atmosphere. During the question and answer session, the participants 'abilities were explored well, seen from the participants' enthusiasm and the number of

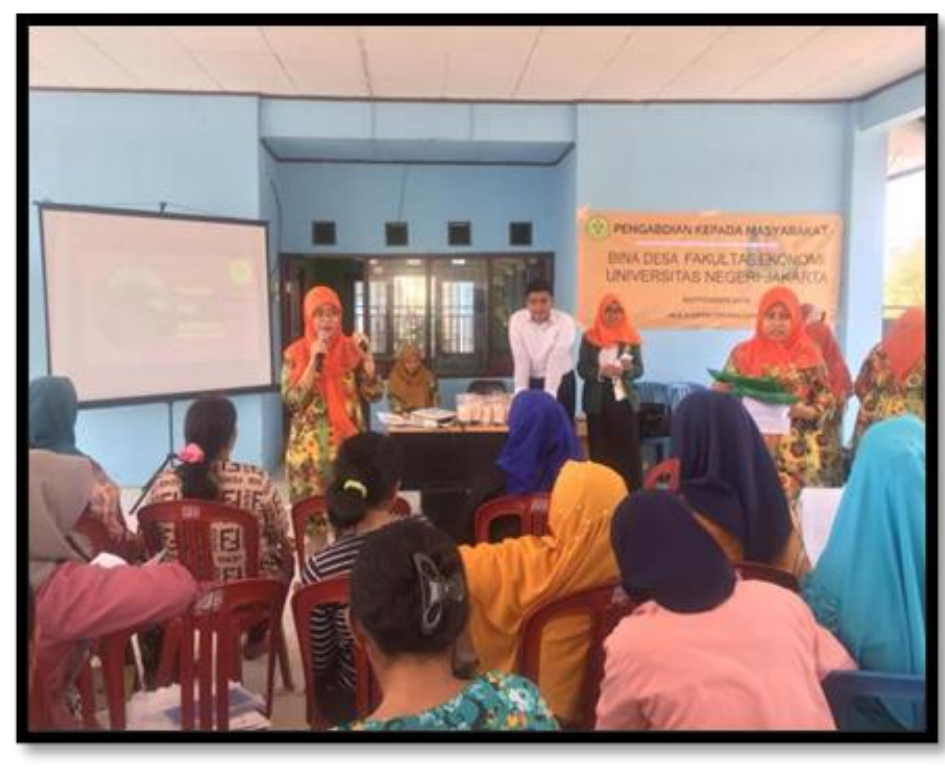

Image 1.

Presentation of Material by Service Team 
questions. Besides, the results of the questionnaire stated that the partners were satisfied and felt the benefits of the training.

\section{Recommendation}

The training activities were very attractive to the participants as SME practitioners, some even suggested that further activities could be carried out. Therefore, this training activity for SMEs needs to be continued in various regions to encourage the advancement of SMEs in Indones ia.

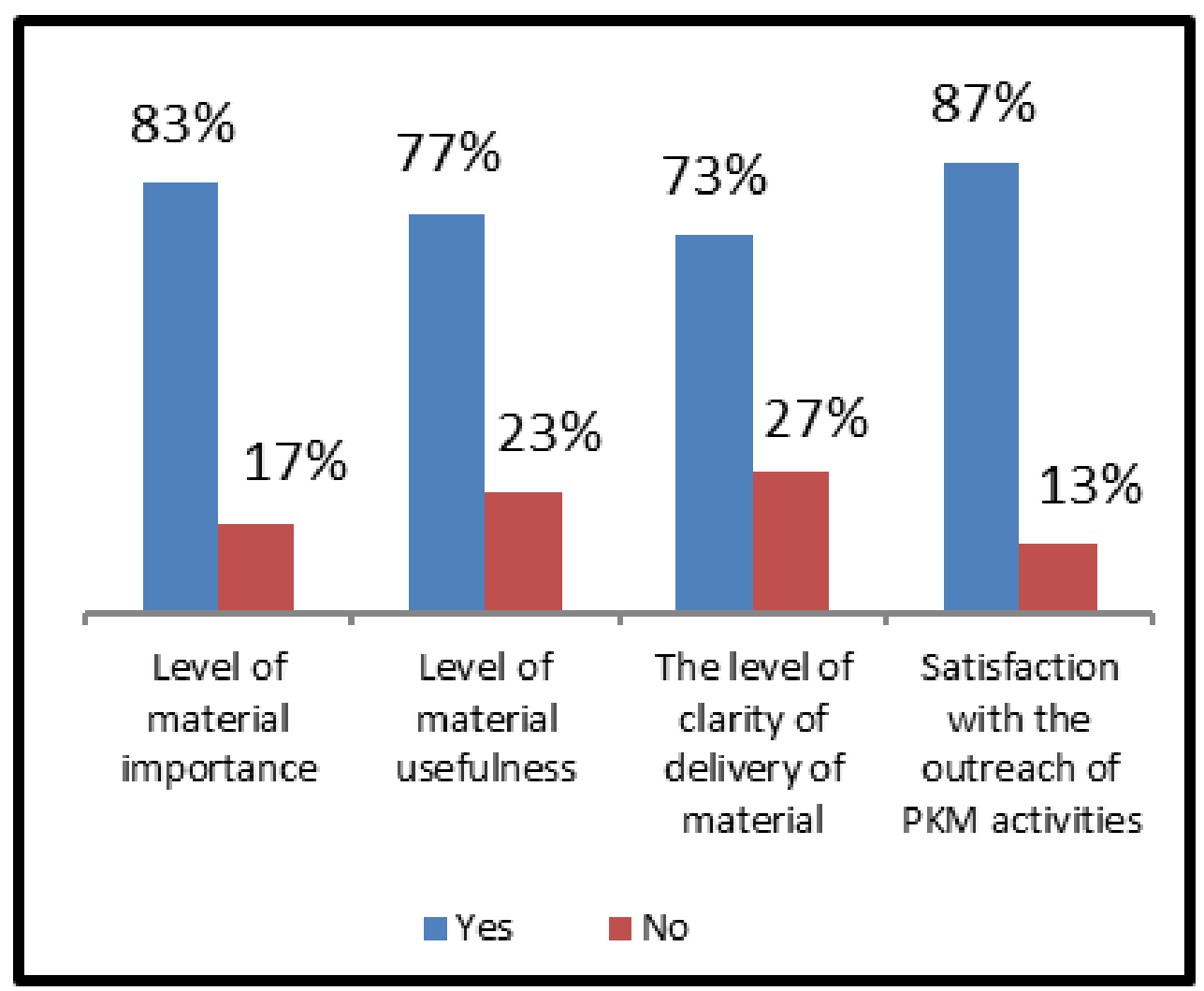

Diagram 1.

Presentation of Material by Sevice Team 


\section{REFERENCES}

Devi, Afriana. (2018). Analisis Pengelolaan Keuangan Dalam Enterpreneurship. Jurusan Manajemen. Universitas Komputer Indonesia, Bandung.

Karim, S \& Hamdan, U. (2014). Analisis Modal Kerja Industri Kecil Usaha Pertukangan Kayu dan Usaha Las di Kota Palembang. Jurnal Manajemen dan Bisnis Sriwijaya Vol 12 (3): 209-229.

Ministry Of Trade. (2013). Analisis Peran Lembaga Pembiayaan Dalam Pengembangan UMKM. Pusat Kebijakan Perdagangan Dalam Negeri. Badan Pengkajian Dan Pengembangan Kebijakan Perdagangan.

Murdayanti, Yunika. (2017). Anggaran Perusahaan : Konsep dan Aplikasi. In Media, Jakarta.

Nasirah. (2016). Analisis Transparansi dan Akuntabilitas Pengelolaan Alokasi Dana Desa (Studi Pada Desa Mulyoagung, Kecamatan Dau. Program Studi Akuntansi, Universitas Muhammadiyah Malang

Poerwanto, Hendro. (2017). Penganggaran Perusahaan.

https://sites.google.com/site penganggaranperusahaan

Prawagis, F., D., Zahroh., \& Mayowan. (2016). Pengaruh Pemahaman atas Mekanisme Pembayaran Pajak, Persepsi Tarif Pajak dan Sanksi Pajak Terhadap Kepatuhan Wajib Pajak UMKM. Jurnal Perpajakan (JEJAK), Vol 10(1): 1-8.

Putra (2018). Pengelolaan Usaha dan Strategi Kewirausahaan. Universitas Brawijaya
Putriyanti, Aprisiami. (2012). Penerapan Otonomi dalam Menguatkan Akuntabilitas Pemerintah Desa dan Pemberdayaan Masyarakat di Desa Aglik Kecematan Grabag Kabupaten Purwerejo. Jurnal ECivics. Volume 1 Nomor 2. www.eprints.uny.ac.id.

Sujarweni,V. Wiratna. (2015). Akuntansi Desa : Panduan Tata Kelola Keuangan Desa. Pustaka Baru Press. Yogyakarta. 